\title{
Interaction of salinity and temperature on the germination of alfalfa cv CUF 101
}

\author{
HA Esechie \\ Department of Plant Sciences, Sultan Qaboos University, PO Box 32484, Muscat, Sultanate of Oman
}

(Received 13 May 1992; accepted 8 February 1993)

\begin{abstract}
Summary - Alfalfa, Medicago sativa $L$ is a major forage legume in the arid climate of the Gulf countries where salinity is a serious production problem. A laboratory experiment was initiated to evaluate the effect of salinity - temperature interactions on the germination of alfalfa cV CUF 101. The alfalfa seeds were sown in Petri dishes with saline solutions of varying concentrations (electrical conductivities of $0.01,6.4,12.2,17.4,22.6,27.2,32.1$ and $37.2 \mathrm{dSm}^{-1}$ ) prepared with $\mathrm{NaCl}$. The germination response of the seeds were determined over a wide range of temperatures (15, $20,25,30,35$ and $40^{\circ} \mathrm{C}$ ) for a period of $8 \mathrm{~d}$. Germination counts, taken every $2 \mathrm{~d}$, were used to compute germination rate index. Generally, germination percentage decreased with increasing salinity and was severely limited at $40^{\circ} \mathrm{C}$. Salinity-temperature interactions were highly significant. The optimum germination temperature was $20-25^{\circ} \mathrm{C}$. Based on these results, the most favourable period to establish alfalfa cV CUF 101 in the Sultanate of Oman and other areas with similar climatic conditions has been proposed.
\end{abstract}

salinity-temperature / interaction / optimum germination / germination rate index / Medicago sativa L

Résumé - Interaction de la salinité et de la température sur la germination de la luzerne cv CUF 101. La luzerne Medicago sativa $L$ représente une culture fourragère importante dans les régions arides des pays du golfe arabo-persique où la salinité constitue un problème majeur pour la production. Un travail de laboratoire a été initié pour évaluer l'effet des interactions température $x$ salinité sur la germination des semences du cv CUF 101. Des solutions de $\mathrm{NaCl}$ (ayant pour conductivités électriques $0,01,6,4,12,2,17,4,22,6,27,2,32,1$ et $37,2 \mathrm{dSm}^{-1}$ ) sont utilisées pour étudier la germination des semences en boites de Petri à des températures variées $\left(15,20,25,30,35\right.$ et $\left.40^{\circ} \mathrm{C}\right)$. L'index de germination est défini par le nombre de semences germées tous les 2 jours. Le pourcentage de germination diminue en fonction de l'augmentation de la salinité pour atteindre une valeur très faible à $40^{\circ} \mathrm{C}$. Les interactions température $x$ salinité sont hautement significatives. La température optimale de germination est comprise entre 20 et $25^{\circ} \mathrm{C}$. La meilleure période pour l'établissement de la luzerne cv CUF 101 dans le sultanat d'Oman et dans les zones à climat similaire est suggérée d'après les résultats.

interaction / salinité et température / germination optimale / indice de germination / Medicago sativa L

\section{INTRODUCTION}

Germination is one of the most critical periods for a crop subjected to salinity (Fowler, 1991). Germination failures on saline soils are often a result of high salt concentrations in the seed planting zone because of the upward movement of soil solution and subsequent evaporation at the soil surface (Bernstein and Hayward, 1958). Since the soil surface is normally more saline than lower layers (Uhvits, 1946; Dotzenko and Dean, 1959; Khatib and Massengale, 1966) seed germinaton occurs in a more saline environment than that in which established plants grow.

Several researchers have observed a decrease in germination rate as salinity increases and the osmotic potential of the germination medium decreases (Abel and Mackenzie, 1946; François et al, 1969; Greenway, 1973; Redmann, 1974; Sharma, 1976). The effects of temperature-salinity interactions on the germination of some crop plants have also been reported (Ungar, 1967; Tadmor et al, 1969). In al- 
falfa, salinity and temperature stresses are primary limiting environmental conditions which restrict its successful establishment in irrigated and semi-arid regions (Stone et al, 1979). Although it has been shown that salinity is increasingly detrimental to alfalfa germination at high temperatures (Ahi and Powers, 1938; Uhvits, 1946) and that low salt concentrations tend to stimulate its germination (Mulwani and Polland, 1938), little is known about the interaction of salinity and temperature on germination of this forage species.

About one-third of developed agricultural land in arid and semi-arid regions is affected by salinity (Allison, 1964). In most of the Gulf countries, saline soils and saline irrigation constitute a serious production problem for alfalfa. In this region, especially the Batinah Coast of Oman, where ocean spray and ocean water intrusion are additional sources of salinity, alfalfa plants affected by salinity are generally stunted and have smaller leaves than normal plants. They are usually dark-green or the leaves may have a bluishgreen cast, probably due to wax accumulation. Thus, apart from yield reduction, salinity also affects the quality of alfalfa. Therefore, a better understanding of the effects of salinity and temperature, as well as their interactions on germination of this forage crop is important in the development of cultural practices for its establishment under saline conditions. The objective of this study was to investigate the germination response of alfalfa cV CUF 101 to a wide range of salinity levels and temperature and to determine their interactions.

\section{MATERIALS AND METHODS}

Several alfalfa seed lots were obtained from the Yates Seed Company in Australia and subjected to preliminary laboratory germination tests. Seeds for the current study were selected from the lot with the highest germination rates (95-100\%).

A stock solution was prepared with reagent grade $\mathrm{NaCl}$ and from this, different concentrations $(60,120$, $180,240,300,360$ and $420 \mathrm{mmol}^{-1}$ ) were prepared by dilution. The electrical conductivities as well as the osmotic potentials of these solutions were determined with a conductivity meter, Model PCM 3 (Jenway Felstead, Essex) and the advanced tigemetric osmometer, Model 3T-II (Advanced Instruments, Boston, MA), respectively (see table I).

Several 90-mm triple vent Petri dishes into which 3 circles of Whatman No 1 filter paper had been placed were prepared. One hundred seeds of alfalfa cv CUF 101 were placed in each of them and $5 \mathrm{ml}$ distilled wa- ter or the various $\mathrm{NaCl}$ solutions were added. The Petri dishes were covered and arranged in an incubator in a randomized complete block design. Germination response to salinity at 6 temperatures $(15,20,25$, 3035 and $40^{\circ} \mathrm{C}$ ) was evaluated by replicating the temperature twice in the same incubator over time. Temperatures were maintained within $\pm 1^{\circ} \mathrm{C}$ of target levels.

Germination counts were taken at 2, 4, 6 and $8 d$ after sowing (DAS). Seed germination was determined by radicle protrusion through the seed coat, in accordance with the Association of Official Seed Analysts (AOSA, 1970) definition of germination. Distilled water equal to the mean loss of water from dishes with only water was added to each Petri dish on $\mathrm{d} 2,4$ and 6 to maintain salt concentration near target levels throughout the germination period. A germination rate index (GRI) was determined following the procedure described by Bouton et al (1976) as modified by Fowler (1991). According to the formula,

$$
\mathrm{GRI}=\mathrm{G} 2 / 2+\mathrm{G} 4 / 4+\mathrm{G} 6 / 6+\mathrm{G} 8 / 8
$$

where G2, G4, G6 and G8 are germination percentages $\times 100$ at 2, 4, 6 and 8 DAS. The data were subjected to analysis of variance and orthogonal contrasts (SAS, 1985).

\section{RESULTS}

The germination responses of alfalfa cV CUF 101 seed to a wide range of salinity and temperature treatments are shown in figure 1. Temperaturesalinity interactions were highly significant at each counting date (table II). The optimum germination temperature for the control was $25^{\circ} \mathrm{C}$. The cumulative germination percentage for the lower salinities (6.4-12.2 $\left.\mathrm{dSm}^{-1}\right)$ also peaked at $25{ }^{\circ} \mathrm{C}$, while salinity levels of $17.4-37.2 \mathrm{dSm}^{-1}$

Table I. Description of $\mathrm{NaCl}$ solutions used to determine the germination response to alfalfa cV CUF 101 seed to salinity.

\begin{tabular}{ccc}
$\begin{array}{c}\text { Concentration } \\
\left(m \text { mol }^{-1}\right)\end{array}$ & $\begin{array}{c}\text { Electrolytic } \\
\left(d S m^{-1}\right)\end{array}$ & $\begin{array}{c}\text { Osmotic potential } \\
(\mathrm{MPa})\end{array}$ \\
\hline & & \\
0 & 0.01 & -0.007 \\
60 & 6.4 & -0.246 \\
120 & 12.2 & -0.469 \\
180 & 17.4 & -0.693 \\
240 & 22.6 & -0.923 \\
300 & 27.2 & -1.259 \\
360 & 32.1 & -1.376 \\
420 & 37.2 & -1.649 \\
\hline
\end{tabular}



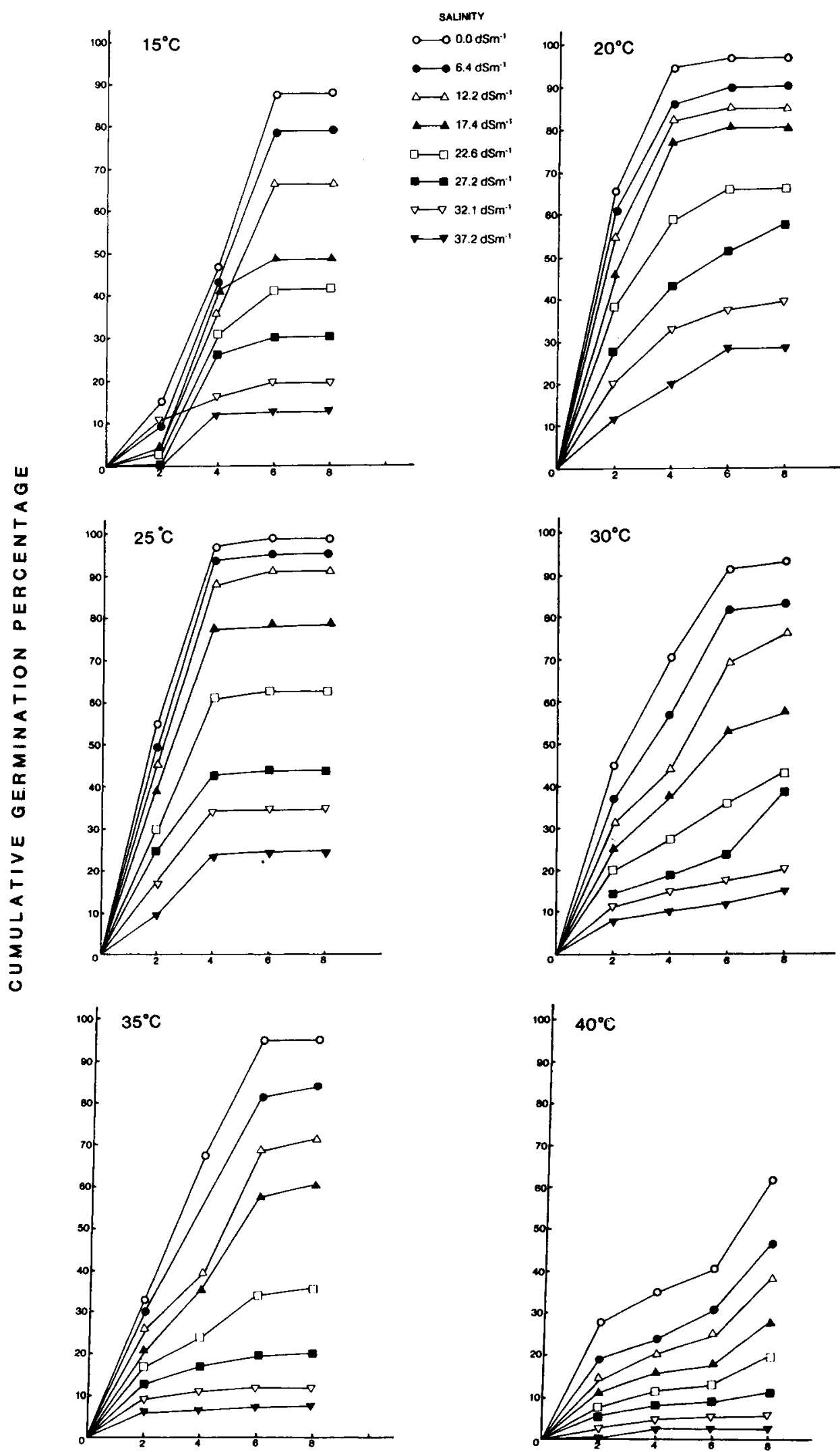

DAYS AFTER SOWING

Fig 1. Cumulative germination percentage of alfalfa cr CUF 101 showing response to varied salinity levels at 6 temperature settings. 
Table II. Analysis of variance for the cumulative germination of alfalfa cV CUF 101 at 6 germination temperatures and 8 salinity levels over an 8-d germination period.

\begin{tabular}{|c|c|c|c|c|c|}
\hline \multirow[t]{3}{*}{ Source } & \multirow[t]{3}{*}{$d f$} & \multicolumn{4}{|c|}{ Mean squares } \\
\hline & & \multicolumn{4}{|c|}{ Cumulative germination - days after sowing } \\
\hline & & 2 & 4 & 6 & 8 \\
\hline Temperature (T) & 5 & 4385.50 ** & $8943.44^{\star \star}$ & $7612.04^{\star \star}$ & $5426.92^{\star *}$ \\
\hline Linear & 1 & $606.00^{\star \star}$ & $14030.37^{\star \star}$ & $18097.74^{\star \star}$ & $11180.68^{* \star}$ \\
\hline Quadratic & 1 & $12635.02^{\star \star}$ & 19332.86 ** & $16343.06^{\star *}$ & $13860.02^{\star \star}$ \\
\hline Cubic & 1 & $6529.33^{\star \star}$ & $7800.46^{\star \star}$ & $518.06^{\star \star}$ & $832.13^{\star \star}$ \\
\hline Salinity (S) & 7 & $2563.18^{\star \star}$ & 7336.96 ** & 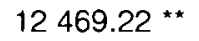 & $13421.30^{* *}$ \\
\hline Linear & 1 & $17908.36^{\star \star}$ & 51117.56 ** & $86657.19^{\star \star}$ & $93488.95^{\star *}$ \\
\hline Quadratic & 1 & 30.36 & 0.66 & 16.30 & 0.70 \\
\hline Cubic & 1 & 0.15 & 52.82 & 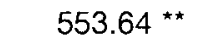 & $411.28^{\star *}$ \\
\hline$T \times S$ & 35 & $96.69^{\star \star}$ & $207.21^{\star \star}$ & $196.21^{\star \star}$ & $111.70^{* *}$ \\
\hline Error & 96 & 2.26 & 11.46 & 11.80 & 24.26 \\
\hline
\end{tabular}

** Significant at $P=0.01$.

peaked at $20^{\circ} \mathrm{C}$ (fig 2). Germination percentages at the upper salinities $\left(32.1-37.2 \mathrm{dSm}^{-1}\right)$ were very poor, with none attaining $50 \%$. At the lower salinities, however, germination percentages were $>50 \%$ at all temperatures with the exception of $40^{\circ} \mathrm{C}$ where depressed germination percentages were obtained.

Germination rate expressed as germination rate index (GRI) was influenced by salinity and temperature in a similar pattern to final germination (fig 3). GRI at 20 and $25^{\circ} \mathrm{C}$ were similar throughout the range of salinities, but were significantly higher than all other temperatures. Germination temperature of $40^{\circ} \mathrm{C}$ had the least GRI, ranging from 26 at $6.4 \mathrm{dSm}^{-1}$ to 2.0 at 37.2 $\mathrm{dSm}^{-1}$.

Generally, salinity levels at which $50 \%$ reduction in germination occurred varied between temperatures. At $20^{\circ} \mathrm{C}, 23.5 \mathrm{dSm}^{-1}$ salinity gave $50 \%$ reduction in germination, while $21.5 \mathrm{dSm}^{-1}$ salinity caused a similar reduction at $25^{\circ} \mathrm{C}$. At 30 and $35^{\circ} \mathrm{C}$, salinity levels at which $50 \%$ reduction in germination occurred were 11.0 and 8.0 $\mathrm{dSm}^{-1}$, respectively.

\section{DISCUSSION}

The optimum germination temperature for the control was $25^{\circ} \mathrm{C}$, which was in agreement with the recommended temperature for measuring germination of legumes (AOSA, 1970). Brar et al (1991), working with 20 forage legumes, including several alfalfa cultivars, obtained germination temperature optima of $15-25^{\circ} \mathrm{C}$, but suggested that cultivars within the same species could respond differently to changes in temperature regimes, possibly due to genetic variability among cultivars.

Germination was greatly depressed at $40^{\circ} \mathrm{C}$ throughout the range of salinity, $46 \%$ being the maximum percentage obtained at 8 DAS even at the lowest salinity of $6.4 \mathrm{dSm}^{-1}$. This relatively low germination response at $40^{\circ} \mathrm{C}$ was an indication that this temperature is outside the maximum germination temperature for alfalfa cv CUF 101. Earlier workers (Ahi and Powers, 1938; Tadmor et al, 1969; Sharma, 1976; Stone et al, 1979) observed that higher temperatures increased the detrimental effect of salinity during germination. $\mathrm{Na}^{+}$and $\mathrm{Cl}^{-}$are potentially toxic and their entry into the seed in high concentrations will have an adverse effect on embryo viability, thus reducing germinability. It has been shown that $\mathrm{Na}^{+}$frequently enhances membrane leakage (Epstein, 1972) and it is more likely that this phenomenon is aggravated by high temperatures. The entry of $\mathrm{Na}^{+}$and $\mathrm{Cl}^{-}$into the seed is therefore facilitated. Denaturation of nucleic acids, protein and membranes at high temperatures are some factors contributing to germina- 


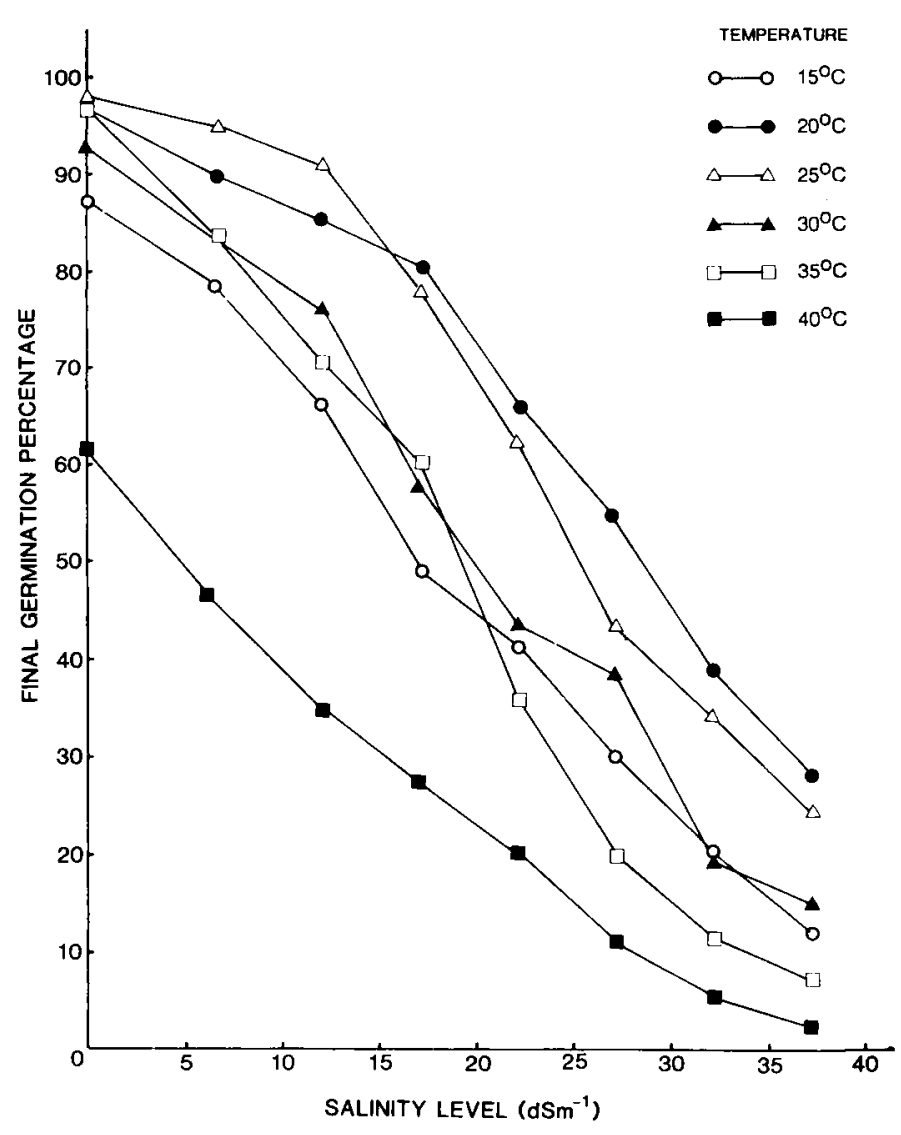

Fig 2. Final germination percentages of alfalfa cV CUF 101 at $8 \mathrm{~d}$ after sowing as a function of salinity and temperature.

tion failure, as has been observed by Cardwell (1984). Obviously factors which increase evaporative demands such as temperature would tend to aggravate the effects of salinity, as has been reported by Hoffman and Jobes (1978).

At the optimal germination temperatures (20$25^{\circ} \mathrm{C}$ ), the salinity levels that reduced germination by $50 \%$ were in the 21.5 to $23.5 \mathrm{dSm}^{-1}$ range. Based on the salt tolerance categories established by Maas and Hoffman (1977), these salinity levels fall within the moderate salinity range. Accordingly, alfalfa cv CUF 101 would be classified as moderately tolerant to salinity.

However, GRI which is a measure of seedling vigour should involve not only germination but emergence characteristics. Therefore, it seems likely that vigour includes the capacity to mobilize seed resources (improved protein synthesis in the embryo) for the process of germination and subsequent plumule elongation. Faster plumule elongation and perhaps longer final length are important factors contributing to high germination percentages in maize (Riley, 1981) and this may also hold true for alfalfa.

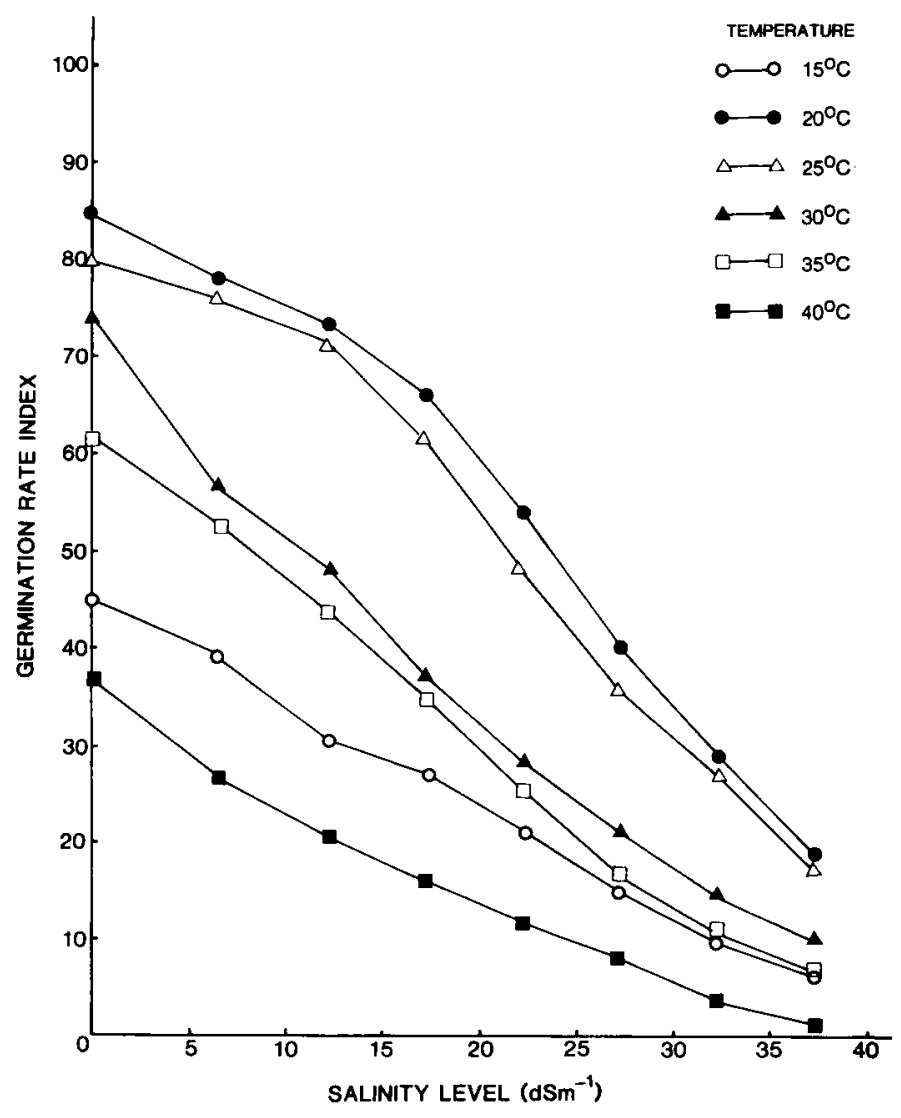

Fig 3. Germination rate index of alfalia cv CUF 101 at $8 \mathrm{~d}$ after sowing as a function of salinity and temperature.

The soils in the Gulf countries, especially the Batinah Coast of Oman, are very saline. The winters are relatively short, while the summers are long and hot. Therefore, it seems that the most ideal period to establish alfala cV CUF 101 in this region is about March to early April when soil temperatures are $\approx 20-25^{\circ} \mathrm{C}$. After this period, soil temperatures increase rapidly due to the summer heat, thus aggravating the detrimental effect of salinity.

\section{ACKNOWLEDGMENTS}

The technical assistance of $\mathrm{V}$ Rodriguez and $\mathrm{H} \mathrm{Al-Asmi}$ is gratefully acknowledged. A Dorvlo is also thanked for his assistance in the statistical analysis of the data.

\section{REFERENCES}

Abel GH, Mackenzie AJ (1964) Salt tolerance of soybean varieties (Glycine max $L$ Merrill) during germination and later growth. Crop Sci 4, 157-161

Ahi SM, Powers SL (1938) Salt tolerance in plants at various temperatures. Plant Physiol 13, 767-789 
Allison LE (1964) Salinity in relation to irrigation. $A d v$ Agron 16, 130-180

Association of Official Seed Analysts (1970) Rules for testing seed. Proc Assoc Off Seed Ana/60, 1-116

Bernstein L, Hayward HE (1958) Physiology of salt tolerance. Annu Rev Plant Physiol 9, 25-46

Bouton JH, Dudeck AE, Smith RL (1976) Germination in freshly harvested seed of centipede grass. Agron J 68, 991-992

Brar GS, Gomez JF, McMichael BL, Matches AG, Taylor HM (1991) Germination of twenty forage legumes as influenced by temperature. Agron J 83, 173-175

Cardwell VB (1981) Seed germination and crop production. In: Physiological Basis of Crop Productivity (Tesar MB, ed) Am Soc Agron, Madison, 53-92

Dotzenko AD, Dean JG (1959) Germination of six alfalfa varieties at three levels of osmotic pressure. Agron J 51, 308-309

Epstein E (1972) Mineral Nutrition of Plants: Principles and Perspectives. John Wiley, New York

Fowler JL (1991) Interaction of salinity and temperature on the germination of crame. Agron J 83, 169172

François LE, Donovan T, Mass EV (1984) Salinity effects on seed yield, growth and germination of grain sorghum. Agron J76, 741-744

Greenway $H$ (1973) Salinity, plant growth, and metabolism. J Aust Inst Agric Sci 39, 24-34

Hoffman GT, Jobes JA (1978) Growth and water relaton of cereal crosp as affected by salinity and relative humidity. Agron J 70, 765-769
Khatib KH, Massengale MA (1966) Effect of certain salts on germination of alfalfa and berseem clover seed. Proc Agric Ariz 18, 21-23

Maas EV, Hoffman GJ (1977) Crop salt tolerancecurrent assessment. J Irrig Drainage Div Am Soc Civ Eng 103, 115-134

Mulwani BT, Polland AG (1938) Effects of alkali salts on germination of seeds. Agric Livest Ind 9, 548555

Redmann RE (1974) Osmotic and specific ions effects on germination of alfalfa. Can J Bot 52, 803-808

Riley GJP (1981) Effects of high temperature on protein synthesis during germination on maize ( $\mathrm{Zea}$ mays L). Planta 151, 75-80

SAS Institute (1985) SAS User's Guide: Statistics. Version 5. SAS Institute, Cary, NC

Sharma ML (1976) Interaction of water potential and temperature effects on germination of three semiarid plant species. Agron J 68, 390-394

Stone JE, Marx DB, Dobrenz AK (1979) Interaction of sodium chloride and temperature on germination of two alfalfa cultivars. Agron J 71, 425-427

Tadmor NH, Cohen Y, Harpaz $Y$ (1969) Interactive effects of temperature and osmotic potential on the germination of range plants. Crop Sci 9, 771774

Uhvits R (1946) Effect of osmotic pressure on water absorption and germination of alfalfa seed. $A m \mathrm{~J}$ Bot 33, 278-285

Ungar TA (1967) Influence of salinity and temperature on seed germination. Ohio J Sci 67, 120-123 